\title{
Skeletal and Joint Manifestations of Primary Immunodeficiency Diseases
}

\author{
Asal Gharib* and Sudhir Gupta \\ Programs in Primary Immunodeficiency and Aging, Division of Basic and Clinical Immunology, University of California, Irvine, USA
}

Received: May 23, 2016; Accepted: June 16, 2016; Published: June 24, 2016

*Corresponding author: Asal Gharib, Division of Basic and Clinical Immunology, University of California at Irvine, Medical Sci. I, C-240, Irvine,CA 92697, USA, Tel: +949-824-5818; Fax: +949-824-4362; E-mail: agharib@ uci.edu

\begin{abstract}
Absract
Primary Immunodeficiencies (PIDs) occur due to inherited disorders in the innate or adaptive immune systems, or combinations of disorders in both. The underlying disorder may be attributed to decreased levels, decreased function, or complete nonfiction of immune components. There are 200 different PIDs and more than 270 genes have been described that are associated with or cause PIDs. These PIDs have recently been re-classified into nine different categories using the International Union of Immunological Societies (IUIS) classification of Primary Immunodeficiencies. This review highlights the different manifestations, including infectious as well as noninfectious etiologies that may occur in the skeletal system of patients with primary Immunodeficiencies.
\end{abstract}

Keywords: Primary immunodeficiency; Arthritis; Osteopenia; Osteomyelitis; Bone findings; Skeletal findings; Bone anomalies; Joint findings

\section{Introduction}

Primary Immune deficiencies (PIDs) are inherited disorders that qualitatively or quantitatively affect components of the innate and adaptive immune systems. The pulmonary [1], dermatological [2], gastrointestinal [3], rheumatological [4], autoimmune [5], and hematological/oncological [6,7] manifestations of PIDs have been reviewed. However, skeletal manifestations of PIDs have not been reviewed. There are 200 different PIDs and more than 270 genes have been described that are associated with or cause PIDs. Registry data has been used in epidemiological studies to gauge PID prevalence: 5.38/100,000 in France, 5.6/100,000 in Australia, USA 86.3/100,000 inhabitants [8]. Bousfiha and colleagues [9] calculated the number of PID cases based on the prevalence estimates which ranges from 390,546 using the Australian model, 6 million using the USA model while PID registries and Jeffrey Modell Centers list 27,243-60,000 cases. These PIDs have recently been reclassified into nine different categories. PID treatment ranges from immunoglobulin replacement therapy to hematopoietic stem cell transplant [10]. We present a comprehensive review of skeletal and joint manifestations in PIDs according to the most recent classifications.

\section{Methods}

The information offered in this article is based upon PubMed (Medline) and Scopus search engines for the search terms of each individual disease state and one of the following: arthritis, skeletal, musculoskeletal, osteoporosis, osteopenia, or osteomyelitis. The inclusion criteria included Humans and English as the language.

\section{Results}

Skeletal and joint abnormalities in nine different categories are shown in the Tables 1-9. Skeletal abnormalities are discussed in detail.

\section{Discussion}

Patients with certain types of primary immunodeficiencies display a number of musculoskeletal changes. In patients with primary immunodeficiencies, septic arthritis due to pyogenic bacteria or mycoplasmal arthritis is the most common osteoarticular manifestation. In certain PIDs, chronic, noninfectious arthritis resembling rheumatoid arthritis may occur. In this paper we have extensively reviewed musculoskeletal and osteoarticular changes in PIDs and presented them under most recent IUIS primary immunodeficiency classification.

In SCID, a number of patients developing osteomyelitis following BCG vaccination have been reported [11]. A T-B+NK+ SCID patient developed Mycobacteria marinum arthritis and osteomyelitis [12]. Reticular dysgenesis is associated with bone anomalies of square shaped scapular tips and cupped costochondral junctions [13]. Characteristic skeletal changes of anterior rib junction, metaphyseal changes, and scapular squaring have been reported in SCID due to adenosine deaminase deficiency [14,15]. Chronic adenoviral arthritis and microcephaly have been reported in Cernunnos deficiency [16].

In Wiskott- Aldrich syndrome, $29 \%$ of patients have aseptic arthritis [17-20]. Ataxia Telangiectasia has been associated with rickets where all three members of a family had rickets [21]. Ataxia Telangiectasia-like syndrome has been associated with microcephaly in $40 \%$ of patients [22]. Nijmegen-Breakage syndrome (a rare DNA repair disorder characterized by microcephaly, immunodeficiency, and predisposition to 
Table 1: Severe Combined Immunodeficiencies.

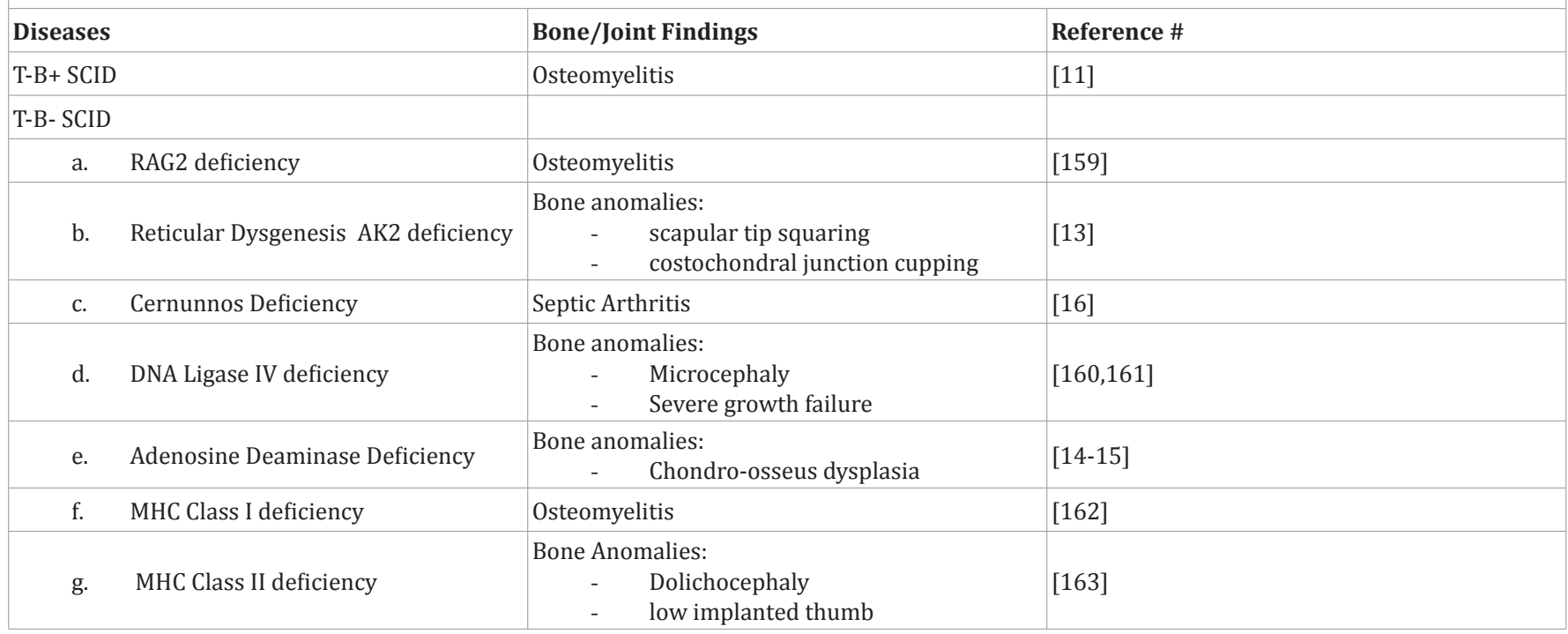

Table 2: Well Defined Syndrome with Immunodeficiencies.

\begin{tabular}{|c|c|c|c|}
\hline \multicolumn{2}{|c|}{ Diseases } & Bone/Joint Findings & Reference \# \\
\hline \multicolumn{4}{|c|}{ Congenital Thrombocytopenia } \\
\hline a. & Wiskott-Aldrich Syndrome & $\begin{array}{l}\text { Aseptic Arthritis } \\
\text { Arthralgia }\end{array}$ & {$[17-20]$} \\
\hline \multicolumn{4}{|c|}{ DNA Repair Defects } \\
\hline & Ataxia-Telangiectasia & $\begin{array}{l}\text { Aseptic Arthritis } \\
\text { Rickets }\end{array}$ & [21] \\
\hline & Ataxia- Telangiectasia Like Disease & Microcephaly & [22] \\
\hline c. & Nijmegen Breakage Syndrome & \begin{tabular}{|ll} 
Bone anomalies: \\
- & hip dysplasia \\
- & rib dysplasia \\
- & sacral genesis \\
- & clinodactyly \\
- & polydactyly \\
- & microcephaly \\
- & scoliosis \\
- & absent thumbs \\
- & Juvenile Idiopathic Arthritis
\end{tabular} & [23-26] \\
\hline & Bloom Syndrome & $\begin{aligned} & \text { Bone anomalies: } \\
&- \text { dolichocephaly } \\
&- \text { short stature }\end{aligned}$ & [27] \\
\hline e. & $\begin{array}{l}\text { Immunodeficiency with centromeric Instability } \\
\text { And Facial Anomalies (ICF) }\end{array}$ & $\begin{aligned} & \text { Bone anomalies: } \\
&- \text { syndactyly } \\
&- \text { Juvenile Idiopathic Arthritis }\end{aligned}$ & [28-30] \\
\hline f. & MCM4 deficiency & Short Stature & [164] \\
\hline \multicolumn{4}{|c|}{ Thymic Defects with additional congenital anomalies } \\
\hline a. & DiGeorge Syndrome & $\begin{array}{l}\text { Bone Anomalies } \\
\text { Juvenile Idiopathic Arthritis }\end{array}$ & {$[31,32]$} \\
\hline \multicolumn{4}{|c|}{ Immune-Osseus Dysplasias: } \\
\hline & Cartilage Hair Hypoplasia & \begin{tabular}{|l} 
Aseptic Arthritis \\
Bone anomalies: \\
$\begin{array}{cl}- & \text { Metaphyseal chondrodysplasia } \\
- & \text { genu varum } \\
- & \text { metaphyseal flaring } \\
- & \text { brachydactyly } \\
- & \text { macrocephaly } \\
- & \text { lordosis }\end{array}$
\end{tabular} & {$[33,34]$} \\
\hline
\end{tabular}




\begin{tabular}{|c|c|c|c|}
\hline b. & Schimke Syndrome & 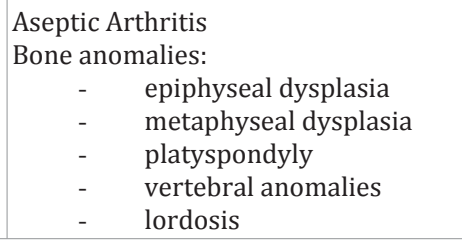 & {$[35,36]$} \\
\hline \multicolumn{4}{|c|}{ Hyper IgE Syndrome } \\
\hline a. & AD-HIES (Job’s Syndrome) & \begin{tabular}{|cl} 
Bone anomalies: \\
- & scoliosis \\
- & recurrent fractures \\
- & Septic Arthritis \\
- & Osteomyelitis
\end{tabular} & {$[37,39,40-46]$} \\
\hline b. & DOCK8 deficiency & $\begin{array}{l}\text { Lupus Arthritis } \\
\text { Scoliosis } \\
\text { Fractures }\end{array}$ & {$[47,48]$} \\
\hline \multicolumn{4}{|c|}{ Dyskeratosis Congenital (DKC) } \\
\hline a. & $\mathrm{XL}-\mathrm{DKC}$ & $\begin{aligned} \text { Bone anomalies: } \\
-\quad \text { phalangeal absorption } \\
-\quad \text { fractures } \\
-\quad \text { avascular necrosis }\end{aligned}$ & {$[49,158]$} \\
\hline b. & AR-DKC due to RTEL deficiency & Microcephaly & [50] \\
\hline c. & AD-DKC due to TERT deficiency & $\begin{array}{l}\text { Bone anomaly } \\
\text { Scoliosis } \\
\text { Osteoporosis }\end{array}$ & {$[51]$} \\
\hline & Netherton Syndrome & $\begin{array}{l}\text { Bone anomalies: } \\
-\quad \text { epiphyseal osteosclerosis } \\
-\quad \text { rickets }\end{array}$ & {$[52,53]$} \\
\hline & ficiency & Bone anomaly: club foot & [54] \\
\hline & deficiency & Juvenile Idiopathic Arthritis & [87] \\
\hline & Teno-Occlusive Disease with immunodeficiency & Microcephaly & [55] \\
\hline & drome & Bone Anomaly: macrocephaly & [56] \\
\hline
\end{tabular}

Table 3: Predominantly Antibody Deficiency.

\begin{tabular}{|c|c|c|}
\hline Diseases & Bone/Joint Findings & Reference \# \\
\hline BTK Deficiency & $\begin{array}{l}\text { Aseptic Arthritis } \\
\text { Septic Arthritis } \\
\text { Aseptic Osteomyelitis } \\
\text { Septic Osteomyelitis }\end{array}$ & {$[57-61]$} \\
\hline$\mu$ heavy chain deficiency & Aseptic Arthritis & {$[62,165]$} \\
\hline$\Lambda 5$ deficiency & Aseptic Arthritis & [63] \\
\hline Thymoma with immunodeficiency (Good Syndrome) & $\begin{array}{l}\text { Aseptic Arthritis } \\
\text { Septic Arthritis }\end{array}$ & {$[64,65]$} \\
\hline Common Variable Immunodeficiency & $\begin{array}{l}\text { Septic Arthritis } \\
\text { Rheumatoid Arthritis } \\
\text { Septic Osteomyelitis }\end{array}$ & {$[66-70,166]$} \\
\hline ICOS deficiency & Rheumatoid Arthritis & {$[71,72]$} \\
\hline TWEAK Deficiency & Osteomyelitis & [73] \\
\hline $\begin{array}{l}\text { Warts, Hypogammaglobulinemia, infection, } \\
\text { Myelokathexis Syndrome (WHIM) }\end{array}$ & Osteomyelitis & [74] \\
\hline CD40L deficiency & Osteomyelitis, Unspecified & [75] \\
\hline AID Deficiency & Aseptic Arthritis & {$[76,77]$} \\
\hline Isolated IgG Subclass deficiency & $\begin{array}{l}\text { Septic Arthritis } \\
\text { Osteomyelitis }\end{array}$ & [78] \\
\hline IgA with IgG subclass deficiency & Rheumatoid Arthritis & [79] \\
\hline PRKC $\delta$ & $\begin{array}{l}\text { Bone Anomalies: } \\
\text {-microcephaly } \\
\text {-polysyndactyly }\end{array}$ & [80] \\
\hline Selective IgA Deficiency & $\begin{array}{l}\text { Juvenile Idiopathic Arthritis } \\
\text { Rheumatoid Arthritis } \\
\text { Osteomyelitis }\end{array}$ & [81-84] \\
\hline
\end{tabular}

Citation: Gharib A, Gupta S (2016) Skeletal and Joint Manifestations of Primary Immunodeficiency Diseases. SOJ Immunol 4(1): 1-13. Page 3 of 13 DOI: http://dx.doi.org/10.15226/2372-0948/4/1/00145 
Table 4: Diseases of Immune Dysregulation.

\begin{tabular}{|c|c|c|}
\hline Diseases & Bone/Joint Findings & Reference \# \\
\hline UNC13D/MUNC 13-4 Deficiency & Juvenile Idiopathic Arthritis & [85] \\
\hline $\begin{array}{l}\text { IPEX (Immune dysregulation, polyendocrinopathy, enteropathy, X-linked } \\
\text { syndrome) }\end{array}$ & Arthritis & [86] \\
\hline $\begin{array}{l}\text { APCED (Autoimmune polyendocrinopathy candidiasis ectodermal } \\
\text { dysplasia) }\end{array}$ & $\begin{array}{l}\text { Short Stature } \\
\text { Juvenile Rheumatoid Arthritis } \\
\text { Osteopenia/Osteoporosis }\end{array}$ & [88] \\
\hline ITCH Deficiency (Human ITCH E3 ubiquitin ligase deficiency) & Arthritis & [89] \\
\hline \multicolumn{3}{|l|}{ Autoimmune Lymphoproliferative Syndrome } \\
\hline ALPS-FAS & Osteopenia & {$[90]$} \\
\hline ALPS-FASL (TNFR) & Arthritis/Arthralgia & [91] \\
\hline \multicolumn{3}{|l|}{ Immune Dysregulation with Colitis } \\
\hline a. $\quad$ IL-10 R $\alpha$ deficiency & Arthritis/Arthralgias & [92] \\
\hline IL-10 R $\beta$ deficiency & Aseptic Arthritis & [92] \\
\hline \multicolumn{3}{|l|}{ Type 1 Interferonopathies } \\
\hline TREX1 deficiency, Aicardi-Goutieres Syndrome & Bone Anomaly: hypoplastic digit(s) & {$[167]$} \\
\hline SAMHD1 deficiency & $\begin{array}{l}\text { Aseptic Arthritis } \\
\text { Microcephaly }\end{array}$ & {$[93,94]$} \\
\hline Spondyloenchondrodysplasia with immune dysregulation & $\begin{array}{l}\text { Bone Anomalies: } \\
\text {-metaphyseal changes } \\
\text {-vertebral changes } \\
\text {-platyspondyly }\end{array}$ & [95] \\
\hline
\end{tabular}

Table 5: Congenital Defects of Phagocytes number, Function or Both.

\begin{tabular}{|c|c|c|c|}
\hline \multicolumn{2}{|c|}{ Diseases } & Bone/Joint Findings & \multirow[t]{2}{*}{ Reference \# } \\
\hline 1. & Defects of Neutrophil Differentiation & $\begin{array}{l}\text { Short Stature } \\
\text { Osteopenia }\end{array}$ & \\
\hline a. & Glycogen storage disease $1 \mathrm{~b}$ & Osteomyelitis & [96] \\
\hline b. & Cyclic Neutropenia & Osteomyelitis & [97] \\
\hline \multicolumn{4}{|c|}{ Defects of Motility } \\
\hline a. & Leukocyte Adhesion Deficiency Type 1 & Septic Osteomyelitis & {$[98,99]$} \\
\hline b. & Leukocyte Adhesion Deficiency Type 2 & 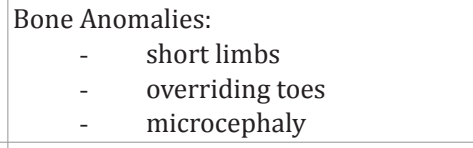 & [100] \\
\hline c. & Leukocyte adhesion deficiency Type 3 & Osteomyelitis & [157] \\
\hline d. & Shwachman-Diamond Syndrome & \begin{tabular}{|rl} 
Bone anomalies: \\
- & metaphyseal abnormalities \\
- & growth plate thickening \\
- & secondary ossification \\
& centers \\
- & coxa valga \\
- & stress fractures \\
- & Osteopenia
\end{tabular} & [101-103] \\
\hline \multicolumn{4}{|c|}{ Defects of Respiratory Burst } \\
\hline a. & X-linked chronic granulomatous disease (CGD) & $\begin{array}{l}\text { Septic Arthritis } \\
\text { Osteomyelitis }\end{array}$ & {$[104-110,168]$} \\
\hline b. & Autosomal recessive CGD-p22 phox deficiency & Septic Osteomyelitis & [111] \\
\hline c. & Autosomal Recessive CGD- p47 phox deficiency & Juvenile Idiopathic Arthritis & [114] \\
\hline d. & Autosomal Recessive CDG p-67 phox deficiency & Septic Osteomyelitis & {$[112,113]$} \\
\hline \multicolumn{4}{|c|}{ Mendelian susceptibility to mycobacterial disease (MSMD) } \\
\hline a. & IL12 and IL23 Receptor $\beta 1$ chain deficiency & $\begin{array}{l}\text { Septic Arthritis } \\
\text { Osteomyelitis }\end{array}$ & [115] \\
\hline b. & GATA2 deficiency & Arthritis & [169] \\
\hline
\end{tabular}


Table 6: Defects in Innate Immunity.

Diseases

Anhidrotic

\begin{tabular}{|c|c|c|}
\hline \multicolumn{3}{|c|}{ Anniarotic Ectoaermal Dysprasia witn immunoaenciency } \\
\hline a. & EDA-ID, X Linked & $\begin{array}{l}\text { Septic Arthritis } \\
\text { Septic Osteomyelitis }\end{array}$ \\
\hline b. & EDA-ID, Autosomal Dominant & $\begin{array}{l}\text { Septic Arthritis } \\
\text { Septic Osteomyelitis }\end{array}$ \\
\hline \multicolumn{3}{|c|}{ TIR signaling pathway defect } \\
\hline a. & IRAK4 deficiency & $\begin{array}{l}\text { Septic Arthritis } \\
\text { Septic Osteomyelitis }\end{array}$ \\
\hline b. & Myd88 deficiency & $\begin{array}{l}\text { Septic Arthritis } \\
\text { Septic Osteomyelitis }\end{array}$ \\
\hline
\end{tabular}

Predisposition to fungal diseases

a. CARD 9 Deficiency

Osteomyelitis

Reference \#

$[116,117$

[116]

Table 7: Autoinflammatory Diseases.

\begin{tabular}{|c|c|c|}
\hline Diseases & Bone/Joint Findings & Reference \# \\
\hline \multicolumn{3}{|l|}{ Defects affecting the inflammasome } \\
\hline a. Familial Mediterranean Fever & $\begin{array}{l}\text { Aseptic Arthritis } \\
\text { Rheumatoid Arthritis } \\
\text { Juvenile Idiopathic Arthritis } \\
\text { Aseptic Osteonecrosis } \\
\text { Osteoporosis }\end{array}$ & {$[121-125]$} \\
\hline Hyper IgD Syndrome & Aseptic Arthritis & [126] \\
\hline c. $\quad$ Muckle-Wells Syndrome & Aseptic Arthritis & {$[127,128]$} \\
\hline $\begin{array}{l}\text { d. Familial Cold Autoinflammatory } \\
\text { Syndrome }\end{array}$ & Arthralgias & {$[129]$} \\
\hline $\begin{array}{l}\text { e. Neonatal Onset Multisystem } \\
\text { inflammatory disease (NOMID) }\end{array}$ & $\begin{array}{l}\text { Aseptic Arthritis } \\
\text { Bone anomalies: } \\
-\quad \text { Hyperostosis } \\
-\quad \text { Contractures }\end{array}$ & {$[130]$} \\
\hline a. $\quad$ TNFR associated periodic fevers & Arthralgia/Arthritis & {$[131]$} \\
\hline $\begin{array}{l}\text { b. Pyogenic sterile arthritis Pyoderma } \\
\text { gangrenosum Acne Syndrome }\end{array}$ & $\begin{array}{l}\text { Aseptic Arthritis } \\
\text { Aseptic Osteomyelitis } \\
\text { Fractures }\end{array}$ & {$[132]$} \\
\hline c. $\quad$ Blau Syndrome & Aseptic Arthritis & {$[133]$} \\
\hline $\begin{array}{l}\text { d. Chronic Recurrent Multifocal } \\
\text { Osteomyelitis and congenital dyserythropoietic } \\
\text { anemia }\end{array}$ & $\begin{array}{l}\text { Aseptic Osteomyelitis } \\
\text { Septic Osteomyelitis }\end{array}$ & {$[134]$} \\
\hline $\begin{array}{l}\text { 1. DIRA (deficiency of the Interleukin } 1 \\
\text { antagonist) }\end{array}$ & $\begin{array}{l}\text { Bone anomalies: } \\
\text {-widened bones } \\
\text {-bone ossification }\end{array}$ & {$[135,136]$} \\
\hline Cherubism & $\begin{array}{l}\text { Bone anomaly: } \\
\text {-jaw resorption } \\
\text { Aseptic Osteomyelitis }\end{array}$ & {$[137]$} \\
\hline $\begin{array}{l}\text { 3. CANDLE (chronic atypical } \\
\text { neutrophilic dermatitis with lipodystrophy) }\end{array}$ & $\begin{array}{l}\text { Bone anomalies: } \\
\text {-microcephaly } \\
\text {-contractures }\end{array}$ & {$[138]$} \\
\hline $\begin{array}{l}\text { 4. PLAID (PLC } \gamma 2 \text { associated antibody } \\
\text { deficiency and immune dysregulation) }\end{array}$ & Aseptic Arthritis & {$[170]$} \\
\hline
\end{tabular}

Table 8: Complement Deficiencies.

\begin{tabular}{|l|l|l|}
\hline Diseases & Bone/Joint Findings & Reference\# \\
\hline C1q deficiency & Lupus Arthritis & {$[139,140]$} \\
\hline C1s deficiency & Lupus Arthritis & {$[141]$} \\
\hline C4 deficiency & Lupus Arthritis & {$[141]$}
\end{tabular}

Citation: Gharib A, Gupta S (2016) Skeletal and Joint Manifestations of Primary Immunodeficiency Diseases. SOJ Immunol 4(1): 1-13. Page 5 of 13 DOI: http://dx.doi.org/10.15226/2372-0948/4/1/00145 


\begin{tabular}{|c|c|c|}
\hline C2 deficiency & $\begin{array}{l}\text { Juvenile Idiopathic Arthritis } \\
\text { Lupus Arthritis } \\
\text { Osteoporosis } \\
\text { Septic Arthritis } \\
\text { Septic Osteomyelitis }\end{array}$ & [142-145] \\
\hline C3 deficiency & $\begin{array}{l}\text { Lupus Arthritis } \\
\text { Osteomyelitis }\end{array}$ & {$[140,142]$} \\
\hline C5 deficiency & $\begin{array}{l}\text { Lupus Arthritis } \\
\text { Septic Arthritis }\end{array}$ & {$[146,147]$} \\
\hline C6 deficiency & $\begin{array}{l}\text { Aseptic Arthritis } \\
\text { Septic Arthritis }\end{array}$ & {$[148,149]$} \\
\hline C7 deficiency & $\begin{array}{l}\text { Rheumatoid Arthritis } \\
\text { Ankylosing Spondylitis } \\
\text { Septic Arthritis }\end{array}$ & {$[150,151]$} \\
\hline C9 deficiency & Ankylosing Spondylitis & {$[152]$} \\
\hline Properdin deficiency & $\begin{array}{l}\text { Septic Arthritis } \\
\text { Septic Osteomyelitis }\end{array}$ & {$[154]$} \\
\hline Factor I deficiency & $\begin{array}{l}\text { Juvenile Idiopathic Arthritis } \\
\text { Septic Arthritis }\end{array}$ & {$[171]$} \\
\hline
\end{tabular}

Table 9: Phenocopies of PID Associated with Somatic Mutations.

\begin{tabular}{|l|l|l|}
\hline Diseases & Bone/Joint Findings & Reference \# \\
\hline $\begin{array}{l}\text { a. Autoimmune lymphoproliferative } \\
\text { Syndrome (ALPS-FAS_ }\end{array}$ & Aseptic Arthritis & {$[155,156]$} \\
\hline
\end{tabular}

malignant lymphomas) is associated with Juvenile Idiopathic Arthritis (JIA)-like clinodactyly, syndactyly, and hip dysplasia [23-26]. In Bloom Syndrome, two patients with dolichocephaly have been reported [27]. In Immunodeficiency with centromeric instability and facial anomalies syndrome, $20 \%$ of patients present with juvenile idiopathic arthritis, 12\% with dolichocephaly, 6\% each had microcephaly or macrocephaly, $7 \%$ had cleft palate, and $5 \%$ had syndactyly [28-30]. DiGeorge syndrome is associated with juvenile idiopathic arthritis, and $20 \%$ with cleft palate and vertebral anomalies [31,32]. A cartilage hair hypoplasia patient was found to have aseptic arthritis [33], while another patient was found to have brachydactyly and femoral bone widening [34]. Aseptic arthritis, platyspondyly, phalangeal anomaly, and clinodactyly have been observed in Schimke syndrome $[35,36]$. Autosomal dominant Hyper IgE Syndrome, which is caused by mutation of STAT-3, is associated with increased frequency of fractures, $66 \%$ hyperextensibility (66\%), scoliosis $(63 \%)$, osteopenia (40\%), osteoporosis (20\%), aseptic arthritis (8\%), and septic arthritis (17\%) [37-43]. Osteogenesis imperfecta as well as craniosynostosis has also been reported [44-46]. Autosomal recessive Hyper-IgE Syndrome, which is caused by DOCK8 mutations, presented with

Systemic Lupus Erythematosus (SLE) with purpuric and necrotic skin lesions diffuse arthritis, and glomerulonephritis [47]. Scoliosis and fractures have been reported in some cases [48]. In autosomal recessive Dyskeratosis Congenita (DKC) due to RTEL (regulation of telomere elongation helicase 1) deficiency, one patient had avascular necrosis [49]. In autosomal recessive DKC, a syndrome characterized by immunodeficiency, bone marrow failure, somatic abnormalities, and cancer predisposition resulting from defective telomere, $80 \%$ have microcephaly [50]. In autosomal dominant DKC due to Telomerase Reverse Transcriptase (TERT) deficiency, 26\% have osteoporosis/ osteopenia and 3\% scoliosis [51]. In Comel-Netherton syndrome, two out of three patients were found to have rickets in addition to the ichthyoses, hair shaft defect, and atopy found in patients that have the disease [52,53]. Oral calcium release activated calcium modulator (ORAI-I) deficiency known for autoimmunity, ectodermic dysplasia, and myopathy also had a case report of skeletal findings of clubfoot and defect of posterior arch closing in a patient [54]. Hepatic veno-occlusive disease with immunodeficiency, 33\% of patients had microcephaly [55]. In facial dysmorphism, immunodeficiency, live do and short stature (FILS) syndrome, patients have facial dysmorphisms, immunodeficiency, live do and short stature with $9 \%$ of patients having macrocephaly [56]. Table 2 has highlighted the specific disease manifestations with the bone findings specific to each disease.

In X-linked Agammaglobulinemia (XLA), a primary immunodeficiency disease caused by mutations in the Bruton's Tyrosine Kinase (BTK) gene, arthritis and osteomyelitis occurs with different frequency; aseptic arthritis (11\%), juvenile idiopathic arthritis (17\%), septic arthritis (8\%), and nonspecific osteomyelitis (3\%) [57-60]. Zhu and associates described a patient with XLA and Juvenile Idiopathic Arthritis (JIA) who later developed invasive Klebsiella pneumonia polyarticular septic 
arthritis [61]. Authors suggested that XLA combined with JIA may contribute to invasive K. pneumoniae infection. A single case of aseptic arthritis has been reported with $\mu$ heavy chain deficiency and $\lambda 5$ deficiency $[62,63]$. Thymoma with immunodeficiency (Good syndrome) has a $2 \%$ risk of septic arthritis (Mycoplasma as implicated species) and one case report of rheumatoid-like arthritis has been reported $[64,65]$. In a cohort of 243 patients with Common Variable Immunodeficiency (CVID), 2\% had rheumatoid arthritis, 1.6\% juvenile idiopathic arthritis, 0.8\% septic arthritis (Mycoplasma pneumoniae, Chlamydia pneumoniae), 0.8\% septic osteomyelitis [66-70]. Rheumatoid arthritis has been reported in patients with ICOS (inducible costimulator) deficiency [7072]. TWEAK (TNF-like weak inducer of apoptosis) deficiency has 33\% osteomyelitis (unknown if septic or chronic) [73]. In Warts, Hypogammaglobulinemia, Infections and Myelokathexis Syndrome (WHIM), $10 \%$ of patients had osteomyelitis [74]. In CD40 ligand deficiency, 1\% had osteomyelitis while 11\% had aseptic arthritis [75]. Activation-Induced Cytidine Deaminase (AID) deficiency had $7 \%$ aseptic arthritis $[76,77]$. In Isolated IgG subclass deficiency, $27 \%$ had septic osteomyelitis with or without septic arthritis with the organisms being staphylococcal species or streptococcal species [78]. In IgA with IgG subclass deficiency, 6\% had rheumatoid arthritis [79]. In PRKC $\delta$ (protein kinase c delta) deficiency, there exists a case report with a patient that had microcephaly and polysyndactyly [80]. In Selective IgA deficiency, 2\% had rheumatoid arthritis, 0.7\% had juvenile idiopathic arthritis, with case reports of ankylosing spondylitis, another of aseptic arthritis, and finally one other with osteomyelitis due to Mycoplasma species [81-84]. Table 3 includes predominantly antibody deficiency syndromes with their respective bone/ joint findings.

In familial hemophagocytic lymphohistiocytosis type 3 due to mutations in UNC13D deficiency; one patient had juvenile idiopathic arthritis [85]. In Immune Dysregulation, Polyendocrinopathy, Enteropathy X linked (IPEX), 33\% of patients had aseptic arthritis [86]. In STAT5b deficiency, patients present with dwarfism, eczema, lymphocytic pneumonitis with $10 \%$ of patients having juvenile idiopathic arthritis [87]. In Autoimmune Polyendocrinopathy with Candidiasis and Ectodermal Dystrophy (APCED), there exists a case report of a patient that had juvenile idiopathic arthritis [88]. In ITCH deficiency, mutations in an E3 ubiquitin ligase called ITCH, patients may have chronic lung disease, autoimmune disease as well as dysmorphic facial features; $90 \%$ of patients had macrocephaly while all patients in the case report of 10 had dolichocephaly [89]. In Autoimmune Lymphoproliferative Syndrome (ALPS) due to FAS mutation, $33 \%$ of patients developed aseptic arthritis, whereas in ALPS due to FASL mutation rarely osteopenia has been reported [90,91]. IL$10 \mathrm{R} \alpha$ and IL-10R $\beta$ deficiency are associated with aseptic arthritis [92]. In Aicardi-Goutieres Syndrome Type 5 due to SAMHD1 mutations, patients present with encephalopathy, cerebral atrophy, vasculitis as well as aseptic arthritis, microcephaly, osteopenia, and sporadic reports of aseptic arthritis and scoliosis $[93,94]$. In case reports of Spondyloenchondrodysplasia with Immune Dysregulation (SPENCD), two patients had vertebral changes and platyspondyly [95]. The bone and joint findings above have also been listed for each disease in Table 4 or Table 9.

In Glycogen storage disease 1b, 32\% had osteopenia, and $12 \%$ had short stature [96]. In cyclic neutropenia, there is a report of a patient with unspecified osteomyelitis [97]. Osseous and joint changes are rare in leukocyte adhesion defect 1 (LAD-1) and LAD-2, while osteomyelitis is frequently (33\%) observed in LAD-3 [98-100]. In Shwachman-Diamond Syndrome, $64 \%$ of patients had osteoporosis, 55\% fractures, and 36\% with osteopenia [101-103]. X-linked Chronic Granulomatous Disease (CGD) is associated with osteomyelitis with a variety of organisms, including Cladophialophora arxii, Aspergillus nidulans, Edwardsiella tarda, Serratia marcescens, Burkholderia gladioli, Chrysosporium zonatum, Paecilomyces Variotii, Pseudoallescheria boydii, Inonotus tropicalis, Penicillium piceum [104-110]. In autosomal recessive CGD-p22 phox and CGD-p67 phox deficiency, patients with osteomyelitis due to Aspergillus fumigatus have been reported [111-113]. In autosomal recessive CGD-p47 phox deficiency, juvenile idiopathic arthritis has been reported [114]. In IL12 and IL23 receptor $\beta 1$ chain deficiency, there is a case report of one patient with cryptococcal arthritis as well as osteomyelitis [115]. The defects found in phagocytes with their respective bone findings have been listed in Table 5. In Ectodermal Dysplasia Agammaglobulinemia (EDA) due to mutation in NEMO, 16\% of patients had arthritis and osteomyelitis [116,117], while in series of EDA due to IKK $\beta 20 \%$ of patients had septic osteomyelitis and arthritis [116]. In IRAK4 deficiency, 29\% of patients had septic arthritis while $14 \%$ had septic osteomyelitis [118]. In MyD88 deficiency, 6\% had septic arthritis and 9\% had osteomyelitis [119]. In CARD9 deficiency, one of five patients was found to have osteomyelitis due to Candidal species [119-120]. The bone and joint findings with the diseases have been listed in Table 6.

In familial Mediterranean fever syndrome, aseptic arthritis $(2 / 2$ patients), rheumatoid arthritis $(2 / 2), 0.8 \%$ juvenile idiopathic arthritis, and ankylosing spondylitis (1/1) have been reported [121-125]. In Hyper IgD Syndrome, 50\% have aseptic arthritis while 4\% have contractures [126]. MuckleWells patients may have arthritis $[127,128]$. In familial cold autoinflammatory syndrome, $96 \%$ of patients have arthralgias [129]. A Neonatal Onset Multisystem Inflammatory Disease (NOMID) patient presented with arthritis while the majority of patients have hyperostosis (92\%), patellar overgrowth (92\%) and contractures (85\%) [130]. TNF-Receptor Associated Periodic Syndrome (TRAPS) is associated with aseptic arthritis and arthralgias [131]. In Pyogenic Sterile Arthritis Pyoderma Gangrenosum Acne (PAPA) syndrome, all patients had aseptic arthritis while $20 \%$ had chronic osteomyelitis [132]. In Blau syndrome, $50 \%$ had aseptic arthritis while the other $50 \%$ of patients in the study had boutonniere's deformity [133]. In chronic recurrent multifocal osteomyelitis and congenital dyserythropoietic anemia, all patients had aseptic osteomyelitis while $12 \%$ had concomitant septic osteomyelitis [134]. In Deficiency of the Interleukin 1 Receptor Antagonist (DIRA), the skeletal anomalies include widened ribs, periosteal reaction, vertebral fusion, and proximal interphalangeal joint swelling $[135,136]$. In addition to the main pathophysiologic finding of fibro-osseous bone formation, craniosynostosis has been 
reported in Cherubism syndrome, where a mutation in $S H 3 B P 2$ causes bone degeneration in the jaws [137]. Microcephaly and contractures have been described in Chronic Atypical Neutrophilic Dermatitis with Lipodystrophy (CANDLE) syndrome [138]. The bone findings with autoinflammatory diseases have been summarized in table 7.

Complement deficiencies have many skeletal manifestations. C1q deficiency has been associated with lupus arthritis in 50\% of cases $[139,140]$. There is a case report of a C1s deficiency also having lupus arthritis [141]. In C4 deficiency, 4\% had lupus arthritis [141]. In C2 deficiency, septic arthritis (Haemophilus influenzae, Streptococcal pneumoniae), septic osteomyelitis (Streptococcal pneumoniae), osteoporosis, fractures, and lupus arthritis have been reported [142-145]. Osteomyelitis has been observed in C3 deficiency [140,142]. There are case reports of gonococcal arthritis in a patient with C5 deficiency [146,147], and septic as well as aseptic arthritis in C6 deficiency [148,149]. C7 deficiency is associated with ankylosing spondylitis and rheumatoid arthritis [150,151]. C9 deficiency has reports of ankylosing spondylitis [152]. In C1 inhibitor deficiency, $0.6 \%$ had lupus arthritis, $0.6 \%$ had rheumatoid arthritis and $0.6 \%$ had polyarthritis [153]. In Properdin deficiency, septic arthritis and osteomyelitis due to Neisseria meningitidis have been reported [154]. Factor I deficiency may present with juvenile idiopathic arthritis or septic arthritis [155-156]. Lastly, the bone findings in complement deficiencies have been summarized in table 8 .

In summary, osteomyelitis and septic and aseptic (rheumatoid arthritis and lupus arthritis, respectively) are the most common osseous and joint manifestations in PID; however frequency of certain other osseous abnormalities may be observed with specific PID syndrome.

\section{Acknowledgement}

This study was supported by funds from the Division of Basic and Clinical Immunology. We would also like to thank Arash Gharib for assisting in editing the paper.

\section{Declarations}

Dr. Gupta is on the advisory board for Baxter and Kedrion, is on the speakers bureau for Baxter, participated in clinical trials with Baxter and Octapharma, received a publication grant from CSL Behring and received a research grant from Baxter, and he is an $\mathrm{Ad}$ Hoc Advisor for Baxalta. Dr. Gharib has no disclosures to report. The authors report no conflicts of interest.

\section{References}

1. Jesenak M, Banovcin P, Jesenakova B, \& Babusikova E. Pulmonary manifestations of primary immunodeficiency disorders in children. Frontiers in Pediatrics. 2014;2:77-90. doi: 10.3389/fped.2014.00077.

2. Lehman H. Skin manifestations of primary immune deficiency. Clinical reviews in allergy \& immunology. 2014;46(2):112-119. doi: 10.1007/ s12016-013-8377-8.

3. Agarwal S, Mayer L. Diagnosis and treatment of gastrointestinal disorders in patients with primary immunodeficiency. Clinical gastroenterology and hepatology. 2013;11(9):1050-1063. doi: 10.1016/j.cgh.2013.02.024.
4. Goyal R, Bulua AC, Nikolov NP, Schwartzberg PL, \& Siegel RM. Rheumatologic and autoimmune manifestations of primary immunodeficiency disorders. Current opinion in rheumatology. 2009;21(1):78-84. doi: 10.1097/BOR.0b013e32831cb939.

5. Seidel MG. Autoimmune and other cytopenias in primary immunodeficiencies: pathomechanisms, novel differential diagnoses, and treatment. Blood. 2014;124(15):2337-2344. doi: 10.1182/blood-2014-06-583260.

6. Zenone T, Souillet G. [Cancer and primary humoral immunodeficiency]. Bulletin du cancer. 1997;84(8):813-821.

7. Kersey JH, Spector BD, Good RA. Primary immunodeficiency diseases and cancer: the immunodeficiency-cancer registry. International journal of cancer. 1973;12(2):333-347.

8. Bousfiha AA, Jeddane L, Ailal F, Benhsaien I, Mahlaoui N, Casanova $\mathrm{JL}$, et al. Primary immunodeficiency diseases worldwide: more common than generally thought. Journal of Clinical Immunology. 2013;33(1):1-7. doi: 10.1007/s10875-012-9751-7.

9. AlHerz W, Bousfiha A, CasanovaJL, Chatila T, Conley ME, CunninghamRundles $\mathrm{C}$, et al. Primary immunodeficiency diseases: an update on the classification from the international union of immunological societies expert committee for primary immunodeficiency. Frontiers in immunology. 2014;5:162. doi: 10.3389/fimmu.2014.00162.

10. Bonilla FA, Khan D A, Ballas Z K, Chinen J, Frank M, Hsu JT, et al. Practice parameter for the diagnosis and management of primary immunodeficiency. Journal of Allergy and Clinical Immunology. 2015;136(5):1186-1205.e1-78. doi: 10.1016/j.jaci.2015.04.049.

11. Hugosson C, Harfi H. Disseminated BCG-osteomyelitis in congenital immunodeficiency. Pediatric radiology. 1991;21(5):384-385.

12. Parent LJ, Salam MM, Appelbaum PC and Dossett JH. Disseminated Mycobacterium marinum infection and bacteremia in a child with severe combined immunodeficiency. Clinical infectious diseases. 1995;21(5):1325-1327.

13. Al Zahrani D, Al Ghonaium A, Al Mousa H, Al Kassar A, \& Roifman C M. Skeletal abnormalities and successful hematopoietic stem cell transplantation in patients with reticular dysgenesis. Journal of allergy and clinical immunology. 2013;132(4):993-996. doi: 10.1016/j.jaci.2013.04.055.

14. Ozdemir O. Severe combined immune deficiency in an adenosine deaminase-deficient patient. Allergy and Asthma Proceedings. 2006;27(2):172-174.

15. Manson D, Diamond L, Oudjhane K, Hussain F B, Roifman C, Grunebam E. Characteristic scapular and rib changes on chest radiographs of children with ADA-deficiency SCIDS in the first year of life. Pediatric radiology. 2013;43(5):589-592. doi: 10.1007/ s00247-012-2564-2.

16. Meyer Bahlburg A, Dressler F, Baumann U. Chronic arthritis in a boy with Cernunnos immunodeficiency. Clinical immunology. 2014;154(1):47-48. doi: 10.1016/j.clim.2014.06.003.

17. Bloom KA, Chung D, Cunningham Rundles C. Osteoarticular infectious complications in patients with primary immunodeficiencies. Current opinion in rheumatology. 2008;20(4):480-485. doi: 10.1097/BOR.0b013e3282fd6e70.

18. Dupuis Girod S, Medioni J, Haddad E, Quartier P, Cavazzana-Calvo M, Le Deist F, et al. Autoimmunity in Wiskott-Aldrich syndrome: risk factors, clinical features, and outcome in a single-center cohort of 55 patients. Pediatrics. 2003;111(5 Pt 1):e622-627. 
19. Sordet C, Cantagrel A, Schaeverbeke T, Sibilia J. Bone and joint disease associated with primary immune deficiencies. Joint bone spine. 2005;72(6):503-514.

20. Akman IO, Ostrov BE, Neudorf S. Autoimmune manifestations of the Wiskott-Aldrich syndrome. Seminars in arthritis and rheumatism. 1998;27(4):218-225.

21. Moin M, Aghamohammadi A, Kouhi A, Tavassoli S, Rezaei N, et al. Ataxia-telangiectasia in Iran: clinical and laboratory features of 104 patients. Pediatric neurology. 2007;37(1):21-28.

22. Fernet M, Gribaa M, Salih M A, Seidahmed M, Hall J and Koenig M. Identification and functional consequences of a novel MRE11 mutation affecting 10 Saudi Arabian patients with the ataxia telangiectasia-like disorder. Human molecular genetics. 2005;14(2):307-318.

23. Pasic S, Cupic M, Jovanovi, Djukic, Kavaric M, Lazarevic I. Nijmegen breakage syndrome and chronic polyarthritis. The Italian Journal of Pediatrics. 2013;39:59. doi: 10.1186/1824-7288-39-59.

24. Nijmegen breakage syndrome The International Nijmegen Breakage Syndrome Study Group Arch Dis Child 2000;82:5 400-406 doi:10.1136/ adc.82.5.400.

25. Chrzanowska KH, Gregorek H, Dembowska Bagińska B, Kalina MA, Digweed M. Nijmegen breakage syndrome (NBS). Orphanet journal of rare diseases. 2012;7:13. doi: 10.1186/1750-1172-7-13.

26. Szczałuba K, Mierzewska H, Obersztyn E, Tryfon J, BekiesińskaFigatowska M, Szczepanik E, et al. Nijmegen breakage syndrome with macrocephaly, schizencephaly and large CSF spaces-extended spectrum of the condition. Journal of Applied Genetics. 2012;53(2):189191. doi: 10.1007/s13353-012-0084-2.

27. Sultan SJ, Sultan ST. Bloom syndrome in two siblings. Pediatric dermatology. 2010;27(2):174-177. doi: 10.1111/j.15251470.2010.01101.x.

28. Kaya N, Al Muhsen S, Al Saud B, Al-Bakheet A, Colak D, Al-Ghonaium A, et al. ICF syndrome in Saudi Arabia: immunological, cytogenetic and molecular analysis. Journal of clinical immunology. 2011;31(2):245252. doi: $10.1007 / \mathrm{s} 10875-010-9488-0$.

29. Hagleitner MM, Lankester A, Maraschio P, Hultén M, Fryns JP, Schuetz $\mathrm{C}$, et al. Clinical spectrum of immunodeficiency, centromeric instability and facial dysmorphism (ICF syndrome). Journal of medical genetics. 2008;45(2):93-99.

30. Franceschini P, Martino S, Ciocchini M, Ciuti E, Vardeu MP, Guala A, et al. Variability of clinical and immunological phenotype in immunodeficiency-centromeric instability-facial anomalies syndrome. Report of two new patients and review of the literature. European journal of pediatrics. 1995;154(10):840-846.

31. Verloes A, Curry C, Jamar M, Herens C, O'Lague P, Marks J, et al. Juvenile rheumatoid arthritis and del(22q11) syndrome: a non-random association. Journal of medical genetics. 1998;35(11):943-947.

32. Kobrynski LJ, Sullivan KE. Velocardiofacial syndrome, DiGeorge syndrome: the chromosome 22q11.2 deletion syndromes. Lancet (London, England). 2007;370(9596):1443-1452.

33. Bacchetta J, Ranchin B, Brunet AS, Bouvier R, Duquesne A, Edery P, et al. Autoimmune hypoparathyroidism in a 12-year-old girl with McKusick cartilage hair hypoplasia. Pediatric nephrology. 2009;24(12):24492453. doi: 10.1007/s00467-009-1256-0.

34. Kwan A, Manning MA, Zollars LK, Hoyme HE. Marked variability in the radiographic features of cartilage-hair hypoplasia: case report and review of the literature. American journal of medical genetics. Part A.

\section{2;158A(11):2911-2916. doi: 10.1002/ajmg.a.35604}

35. Tylki Szymańska A, Pyrkosz, A, Krajewska Walasek M, Michałkiewicz J, Kowalska A, \& Rokicki D. Schimke immuno-osseous dysplasia: two cases. Pediatric radiology. 2003;33(3):216-218.

36. Ozdemir N, Alpay H, Bereket A, Biyikli N, Aydoğan M, Cakalağoğlu $\mathrm{F}$, et al. Membranous nephropathy in Schimke immuno-osseous dysplasia. Pediatric nephrology. 2006;21(6):870-2.

37. Grimbacher B, Holland S M, Puck J M. Hyper-IgE syndromes. Immunological reviews. 2005;203:244-50.

38. Holland SM, DeLeo FR, Elloumi HZ, Hsu AP, Uzel G, Brodsky N, et al. STAT3 mutations in the hyper-IgE syndrome. The New England journal of medicine. 2007;357(16):1608-19.

39. Ma H, Kuang L, Lv G, Wang B, Lian Z. Vertebral aspergillosis in a patient with autosomal-dominant hyper-IgE syndrome. Clinical and vaccine immunology. 2014;21(1):107-9.

40. Yong, PF, Freeman AF, Engelhardt KR, Holland S, Puck JM, Grimbacher B, et al. An update on the hyper-IgE syndromes. Arthritis research \& therapy. 2012;14(6):228-238.

41. Macías Fernández I. Septic arthritis in a case of hyper-IgE syndrome. Reumatologiá clinica. 2010;6(1):53-5.

42. Donabedian H, Gallin J I. The hyperimmunoglobulin E recurrentinfection (Job. Medicine. 1983;62(4):195-208.

43. Buckley RH. The hyper-IgE syndrome. Clinical reviews in allergy \& immunology. 2001;20(1):139-54.

44. Gorgas S, Abuhammour W, Blackwood R A. Hyperimmunoglobulin E syndrome presenting as osteogenesis imperfecta in a 3 year old child. Infectious Disease Reports. 2013;5(1):21-23.

45. Höger PH, Boltshauser E, Hitzig W H. Craniosynostosis in hyperIgE-syndrome. European journal of pediatrics. 1985;144(4):414-7.

46. Brestel EP, Klingberg WG, Veltri RW, Dorn JS. Osteogenesis imperfecta tarda in a child with hyper-IgE syndrome. American journal of diseases of children. 1982;136(9):774-6.

47. Susanne E Aydin, Sara Sebnem Kilic, Caner Aytekin, Ashish Kumar, Oscar Porras, Leena Kainulainen, et al. DOCK8 deficiency: clinical and immunological phenotype and treatment options - a review of 136 patients. J Clin Immunol 2015 ;35(2):189-98.

48. Jouhadi Z, Khadir K, Ailal F, Bouayad K, Nadifi S, Engelhardt $\mathrm{KR}$, et al. Ten-year follow-up of a DOCK8-deficient child with features of systemic lupus erythematosus. Pediatrics. 2014 Nov;134(5):e1458-63. doi: 10.1542/peds.2013-1383.

49. Kalb RE, Grossman ME, Hutt C. Avascular necrosis of bone in dyskeratosis congenita. The American journal of medicine. 1986;80(3):511-3.

50. Ballew BJ, Yeager M, Jacobs K, Giri N, Boland J, Burdett L, et al. Germline mutations of regulator of telomere elongation helicase 1, RTEL1, in Dyskeratosis congenita. Human genetics. 2013;132(4):473-80.

51. Alberto Diaz de Leon, Jennifer T, Cronkhite, Anna-Luise A, Katzenstein, J. David Godwin, et al. Telomere lengths, pulmonary fibrosis and telomerase (TERT) mutations. PLoS ONE. 2010;5(5):111.

52. Magnani C, Bertolin P, Tondelli T, Bassissi G, Ricci R, Bevilacqua G, et alEarly skeletal signs in Netherton syndrome. Pediatric dermatology. 2006;23(6):590-1. 
53. André E, Till M, Descargues P, Cordier MP, Fouilhoux A, Haftek M, et al. Netherton syndrome: a type of infantile erythroderma with failure to thrive, immune deficiency, rickets. Report of 3 cases. Archives de pédiatrie. 2005;12(9):1364-7.

54. McCarl CA, Picard C, Khalil S, Kawasaki T, Röther J, Papolos A, Kutok $\mathrm{J}$, et al. ORAI1 deficiency and lack of store-operated $\mathrm{Ca} 2+$ entry cause immunodeficiency, myopathy, and ectodermal dysplasia. J Allergy Clin Immunol. 2009 ;124(6):1311-1318.e7. doi: 10.1016/j. jaci.2009.10.007.

55. Mellis C, Bale P M. Familial hepatic venoocclusive disease with probable immune deficiency. The journal of pediatrics. 1976;88(2):236-42.

56. Jana Pachlopnik Schmid, Roxane Lemoine,Nadine Nehme, Valéry Cormier-Daire, Patrick Revy, Franck Debeurme et al. Polymerase $\varepsilon 1$ mutation in a human syndrome with facial dysmorphism, immunodeficiency, livedo, and short stature ("FILS syndrome"). The Journal of experimental medicine. 2012;209(13):2323-30.

57. Conley ME, Howard VC. X-Linked Agammaglobulinemia. 2001 Apr 5 [Updated 2011 Nov 17]. In: Pagon RA, Adam MP, Ardinger HH, et al., editors. GeneReviews ${ }^{\circledR}$ [Internet]. Seattle (WA): University of Washington, Seattle;1993-2016. Available from:https://vpn.nacs.uci. edu/+CSC0+1h756767633A2F2F6A6A6A2E61706F762E61797A2E6 $176752 \mathrm{E} 746269$

58. Cuccherini B, Chua K, Gill V, Weir S, Wray B, Stewart D, et al. Bacteremia and skin/bone infections in two patients with X-linked agammaglobulinemia caused by an unusual organism related to Flexispira/Helicobacter species. Clinical immunology. 2000;97(2):1219.

59. Plebani A, Soresina A, Rondelli R, Amato GM, Azzari C, Cardinale F, et al. Clinical, immunological, and molecular analysis in a large cohort of patients with X-linked agammaglobulinemia: an Italian multicenter study. Clinical immunology. 2002;104(3):221-30.

60. Winkelstein JA, Marino MC, Lederman HM, Jones SM, Sullivan K, Burks AW, et al. X-linked agammaglobulinemia: report on a United States registry of 201 patients. Medicine. 2006;85(4):193-202.

61. Zhu Z, Kang Y, Lin Z, Huang Y, Lv H, Li Y, et al. Y.X-linked agammaglobulinemia combined with juvenile idiopathic arthritis and invasive Klebsiella pneumoniae polyarticular septic arthritis. Clinical rheumatology. 2015;34(2):397-401.

62. Yel L, Minegishi Y, Coustan-Smith E, Buckley RH, Trübel H, Pachman LM, Kitchingman GR, et al. Mutations in the mu heavy-chain gene in patients with agammaglobulinemia. The New England journal of medicine. 1996;335(20):1486-93.

63. Minegishi Y, Coustan-Smith E, Wang YH, Cooper MD, Campana D, Conley ME, et al. Mutations in the human lambda5/14.1 gene result in B cell deficiency and agammaglobulinemia. The Journal of experimental medicine. 1998;187(1):71-7.

64. Ardeniz O, Vatansever S, Musabak U, Aksu K, Sin A, Kokuludağ A, et al. Arthritis as a presenting symptom in a hypogammaglobulinemic patient with thymectomy. Rheumatology international. 2007;27(3):263-7.

65. Kelleher P, Misbah S A. What is Good's syndrome-immunological abnormalities with thymomas. Journal of Clinical Pathology. 2003;56(1):12-6.

66. Adams ST, Schmidt KM, Cost KM, Marshall GS. Common variable immunodeficiency presenting with persistent parvovirus B19 infection. Pediatrics. 2012;130(6):e1711-5.

67. Lewandowicz-Uszynska A, Chlebicki A, Szmyrka-Kaczmarek M, Polańska B, Jankowski A, Szechinski J .et al. Rheumatoid arthritis in a patient with common variable immunodeficiency: difficulty in diagnosis and therapy. Clinical rheumatology. 2006;25(1):92-4.

68. Bonilla HF, Chenoweth CE, Tully JG, Blythe LK, Robertson JA, Ognenovski VM, et al. Mycoplasma felis septic arthritis in a patient with hypogammaglobulinemia. Clinical infectious diseases. 1997;24(2):222-5.

69. Takahashi N, Morio T. Common variable immunodeficiency. Nihon Rinsho Meneki Gakkai Kaishi. 2008;31(1):9-16.

70. Cunningham-Rundles C, Bodian C. Common variable immunodeficiency: clinical and immunological features of 248 patients. Clinical immunology. 1999;92(1):34-48.

71. Grimbacher B, Hutloff A, Schlesier M, et al. Homozygous loss of ICOS is associated with adult-onset common variable immunodeficiency. Nature Immunology. 2003;4(3):261-8.

72. Salzer U, Maul-Pavicic A, Cunningham-Rundles C, Urschel S, Belohradsky BH, Litzman J, et al. ICOS deficiency in patients with common variable immunodeficiency. Clinical immunology. 2004;113(3):234-40.

73. Wang HY, Ma CA, Zhao Y, Fan X, Zhou Q, Edmonds P, et al. Antibody deficiency associated with an inherited autosomal dominant mutation in TWEAK. Proc Natl AcadSciUSA. 2013;110(13):5127-32. doi: 10.1073/pnas.1221211110.

74. Dotta L, Tassone L, Badolato R. Clinical and genetic features of Warts, Hypogammaglobulinemia, Infections and Myelokathexis (WHIM) syndrome. Current molecular medicine. 2011;11(4):31725.

75. Winkelstein JA, Marino MC, Ochs H, Fuleihan R, Scholl PR, Geha R, et al. The X-linked hyper-IgM syndrome: clinical and immunologic features of 79 patients. Medicine (Baltimore). 2003;82(6):373-84.

76. Quartier P, Bustamante J, Sanal O, Plebani A, Debré M, Deville A, et al. Clinical, immunologic and genetic analysis of 29 patients with autosomal recessive hyper-IgM syndrome due to Activation-Induced Cytidine Deaminase deficiency. Clin Immunol. 2004;110(1):22-9.

77. Jimenez M J, Steele RW. Recurrent severe arthralgia. Clinical Pediatrics. 2013;52(9):882-5.

78. Beard LJ, Ferris L, Ferrante A. Immunoglobulin G subclasses and lymphocyte subpopulations and function in osteomyelitis and septic arthritis. Acta pædiatrica Scandinavica. 1990;79(6-7):599604.

79. Castrignano SB, Carlsson B, Carneiro Sampaio MS, Söderström T, Hanson LA. IgA and IgG subclass deficiency in a poor population in a developing country. Scandinavian journal of immunology. 1993;37(4):509-14.

80. Woodbine L, Neal JA, Sasi NK, Shimada M, Deem K, Coleman $\mathrm{H}$, et al. PRKDC mutations in a SCID patient with profound neurological abnormalities. The Journal of clinical investigation. 2013;123(7):2969-80.

81. Moradinejad MH, Rafati AH, Ardalan M, Rabiei M, Farghadan M, Ashtiani MT, et al. Prevalence of IgA deficiency in children with juvenile rheumatoid arthritis. Iranian journal of allergy, asthma, and immunology. 2011;10(1):35-40.

82. Terzioğlu E, Kokuludağ A, Sin A, Kirmaz C, Yalçin M, Sebik F, et al. Selective IgA deficiency and ankylosing spondylitis. Journal of investigational allergology \& clinical immunology. 1997;7(6):61920.

83. Camilleri JP, Moore RH, Griffiths DF, Williams BD. Selective IgA 
deficiency associated with glomerulonephritis and oligoarthritis. Annals of the rheumatic diseases. 1992;51(1):123-5.

84. Solhpour A, Hajiabdolbaghi M, Jafari S, Gorouhi F, Shahryaran S, Abdi Z, et al. Subphrenic abscess and recurring focal lesions due to tuberculosis in a patient with IgA deficiency. The Journal of infection. 2007;54(1):e9-12.

85. Hazen MM, Woodward AL, Hofmann I, Degar BA, Grom A, Filipovich AH et al. Mutations of the hemophagocytic lymphohistiocytosis-associated gene UNC13D in a patient with systemic juvenile idiopathic arthritis. Arthritis \& rheumatism. 2008;58(2):567-70.

86. Wildin RS, Smyk Pearson S, Filipovich AH. Clinical and molecular features of the immunodysregulation, polyendocrinopathy, enteropathy, $\mathrm{X}$ linked (IPEX) syndrome. Journal of medical genetics. 2002;39(8):537-45.

87. Nadeau K, Hwa V, Rosenfeld RG. STAT5b deficiency: an unsuspected cause of growth failure, immunodeficiency, and severe pulmonary disease. The journal of pediatrics. 2011;158(5):701-8.

88. Pun T, Chandurkar V. Growth hormone deficiency, short stature, and juvenile rheumatoid arthritis in a patient with autoimmune polyglandular syndrome type 1: case report and brief review of the literature. ISRN Endocrinology. 2011;2011:462759-462759.

89. Naomi JLohr, Jean P. Molleston, Kevin A Strauss, Wilfredo TorresMartinez, Eric A Sherman, Robert H, et al. Human ITCH E3 ubiquitin ligase deficiency causes syndromic multisystem autoimmune disease. American journal of human genetics. 2010;86(3):447-53.

90. Teachey DT, Greiner R, Seif A, Attiyeh E, Bleesing J, Choi J, et al. Treatment with sirolimus results in complete responses in patients with autoimmune lymphoproliferative syndrome. British journal of haematology. 2009;145(1):101-6.

91. Neven B, Magerus-Chatinet A, Florkin B, Gobert D, Lambotte O, De Somer $\mathrm{L}$, et al. A survey of 90 patients with autoimmune lymphoproliferative syndrome related to TNFRSF6 mutation. Blood. 2011;118(18):4798807

92. Kotlarz D, Beier R, Murugan D, Diestelhorst J, Jensen O, Boztug K, et al. Loss of interleukin-10 signaling and infantile inflammatory bowel disease: implications for diagnosis and therapy. Gastroenterology. 2012;143(2):347-55.

93. Dale RC, Gornall H, Singh-Grewal D, Alcausin M, Rice GI, Crow YJ, et al. Familial Aicardi-Goutières syndrome due to SAMHD1 mutations is associated with chronic arthropathy and contractures. American journal of medical genetics. Part A. 2010;152A(4):938-42.

94. Ramantani G, Häusler M, Niggemann P, Wessling B, Guttmann H, Mull M, et al. Aicardi-Goutières syndrome and systemic lupus erythematosus (SLE) in a 12-year-old boy with SAMHD1 mutations. Journal of Child Neurology. 2011;26(11):1425-8.

95. Navarro V, Scott C, Briggs TA, Barete S, Frances C, Lebon P, et al. Two further cases of spondyloenchondrodysplasia (SPENCD) with immune dysregulation. American journal of medical genetics. Part A. 2008;146A(21):2810-5.

96. Melis D, Della Casa R, Balivo F, Minopoli G, Rossi A, Salerno M, et al. Involvement of endocrine system in a patient affected by glycogen storage disease $1 \mathrm{~b}$ : speculation on the role of autoimmunity. The Italian Journal of Pediatrics. 2014;40(1):30.

97. Rezaei N, Farhoudi A, Pourpak Z, et al. Clinical and laboratory findings in Iranian children with cyclic neutropenia. Iranian journal of allergy, asthma, and immunology. 2004;3(1):37-40.
98. Marsili M, Lougaris V, Lucantoni M, Di Marzio D, Baronio M, Vitali M, et al. Successful anti-TNF- $\alpha$ treatment in a girl with LAD-1 disease and autoimmune manifestations. Journal of clinical immunology. 2014;34(7):788-91.

99. Jabbari Azad F, Ardalan M, Hoseinpoor Rafati A, Sotoudeh S, Pourpak Z. Osteomyelitis in leukocyte adhesion deficiency type 1 syndrome. Journal of infection in developing countries. 2010;4(3):175-8.

100. Gazit Y, Mory A, Etzioni A, Frydman M, Scheuerman O, GershoniBaruch R, et al. Leukocyte adhesion deficiency type II: longterm follow-up and review of the literature. Journal of clinical immunology. 2010;30(2):308-13.

101. Myers KC, Davies SM, Shimamura A. Clinical and molecular pathophysiology of Shwachman-Diamond syndrome: an update. Hematology/oncology clinics of North America. 2013;27(1):11728 , ix.

102. Dror Y, Donadieu J, Koglmeier J, Dodge J, Toiviainen-Salo S, Makitie 0 , et al. Draft consensus guidelines for diagnosis and treatment of Shwachman-Diamond syndrome. Annals of the New York Academy of Sciences. 2011;1242:40-55.

103. Toiviainen-Salo S, Mäyränpää MK, Durie PR, Richards N, Grynpas M, Ellis L, Ikegawa S, Cole WG, et al. Shwachman-Diamond syndrome is associated with low-turnover osteoporosis. Bone. 2007;41(6):965-72.

104. Shigemura T, Agematsu K, Yamazaki T, Eriko K, Yasuda G, Nishimura K, et al. Femoral osteomyelitis due to Cladophialophora arxii in a patient with chronic granulomatous disease. Infection. 2009;37(5):469-73.

105. Boyanton BL Jr, Noroski LM, Reddy H, Dishop MK, Hicks MJ, Versalovic J, et al. Burkholderia gladioli osteomyelitis in association with chronic granulomatous disease: case report and review. The Pediatric infectious disease journal. 2005;24(9):837-9.

106. Bielorai B, Toren A, Wolach B, Mandel M, Golan H, Neumann Y, Kaplinisky C, et al. Successful treatment of invasive aspergillosis in chronic granulomatous disease by granulocyte transfusions followed by peripheral blood stem cell transplantation. Bone marrow transplantation. 2000;26(9):1025-8.

107. Dotis J, Pana Z D, Roilides E. Non-Aspergillus fungal infections in chronic granulomatous disease. Mycoses. 2013;56(4):449-62.

108. Roilides E, Sigler L, Bibashi E, Katsifa H, Flaris N, Panteliadis C. Disseminated infection due to Chrysosporium zonatum in a patient with chronic granulomatous disease and review of non-Aspergillus fungal infections in patients with this disease. Journal of clinical microbiology. 1999;37(1):18-25.

109. Campos M, Rocha G, Cordeiro A, Lemos S, Paiva A, Silva I, et al. Serratia osteomyelitis and chronic granulomatous disease. Acta médica portuguesa. 2011;24(3):449-52.

110. Kawai T, Kusakabe H, Seki A, KobayashiS, Onodera M. Osteomyelitis due to trimethoprim/sulfamethoxazole-resistant Edwardsiella tarda infection in a patient with X-linked chronic granulomatous disease. Infection. 2011;39(2):171-3.

111. Sfaihi L, Maaloul I, Fourati H, Stasia MJ, Mnif Z, Hachicha M, et al. Resistant invasive aspergillosis in an autosomal recessive chronic granulomatous disease. Fetal and pediatric pathology. 2013;32(4):241-5.

112. Raptaki M, Varela I, Spanou K, Tzanoudaki M, Tantou S, Liatsis M, Constantinidou N, et al. Chronic granulomatous disease: a 25-year patient registry based on a multistep diagnostic procedure, from 
the referral center for primary immunodeficiencies in Greece. Journal of clinical immunology. 2013;33(8):1302-9.

113. Tsumura N, Akasu Y, Yamane H, Ikezawa S, Hirata T, Oda K, Sakata Y, et al. Aspergillus osteomyelitis in a child who has p67-phox-deficient chronic granulomatous disease. The Kurume Medical Journal. 1999;46(1):87-90.

114. De Ravin SS, Naumann N, Cowen EW, Friend J, Hilligoss D, Marquesen M, et al. Chronic granulomatous disease as a risk factor for autoimmune disease. Journal of allergy and clinical immunology. 2008;122(6):1097-103.

115. Dorman SE, Picard C, Lammas D, Heyne K, van Dissel JT, Baretto R, et al. Clinical features of dominant and recessive interferon gamma receptor 1 deficiencies. Lancet. 2004;364(9451):2113-21.

116. Picard C, Casanova J, Puel A. Infectious diseases in patients with IRAK4, MyD88, NEMO, or IкB $\alpha$ deficiency. Clinical microbiology reviews. 2011;24(3):490-7.

117. Niehues T, Reichenbach J, Neubert J, Gudowius S, Puel A, Horneff G, et al. Nuclear factor kappaB essential modulator-deficient child with immunodeficiency yet without anhidrotic ectodermal dysplasia. Journal of allergy and clinical immunology. 2004;114(6):1456-62.

118. Szabó J, Dobay O, Erdos M, Borbély A, Rozgonyi F, Maródi L, et al. Recurrent infection with genetically identical pneumococcal isolates in a patient with interleukin-1 receptor-associated kinase-4 deficiency. Journal of medical microbiology. 2007;56(6):863-5.

119. von Bernuth H, Picard C, Jin Z, Pankla R, Xiao H, Ku CL, Chrabieh M, et al. Pyogenic bacterial infections in humans with MyD88 deficiency. Science. 2008;321(5889):691-6.

120. Lanternier F, Mahdaviani SA, Barbati E, Chaussade H, Koumar Y, Levy $\mathrm{R}$, et al. Inherited CARD9 deficiency in otherwise healthy children and adults with Candida species-induced meningoencephalitis, colitis, or both. Journal of allergy and clinical immunology. 2015;135(6):155868.

121. Yildirim K, Karatay S, Cetinkaya R, Uzkeser H, Erdal A, Capoglu I, et al. Bone mineral density in patients with familial Mediterranean fever. Rheumatology international. 2010;30(3):305-8.

122. Balaban B, Yasar E, Ozgul A, Dincer K, Kalyon T A. Sacroiliitis in familial Mediterranean fever and seronegative spondyloarthropathy: importance of differential diagnosis. Rheumatology international. 2005;25(8):641-4.

123. Usluer H, Bircan Z. Protracted familial mediterranean fever arthritis presenting as septic arthritis. Rheumatology international. 2007;27(11):1083-5.

124. Matsuoka N, Iwanaga J, Ichinose Y, Fujiyama K, Tsuboi M, Kawakami A, et al. Two elderly cases of familial Mediterranean fever with rheumatoid arthritis. International journal of rheumatic diseases. 2014;

125. Rozenbaum M, Rosner I. Severe outcome of juvenile idiopathic arthritis (JIA) associated with familial Mediterranean fever (FMF). Clinical and Experimental Rheumatology. 2004;22(4 Suppl 34):S75-8.

126. van der Hilst J C, Bodar E J, Barron K S, Frenkel J, Drenth JP, van der Meer JW, et al. Long-term follow-up, clinical features, and quality of life in a series of 103 patients with hyperimmunoglobulinemia D syndrome. Medicine. 2008;87(6):301-310. doi: 10.1097/ MD.0b013e318190cfb7.

127. Eungdamrong J, Boyd K P, Meehan S A, Latkowski J. MuckleWells treatment with anakinra. Dermatology online journal.

\section{3;19(12):20720.}

128. Hawkins PN, Lachmann HJ, Aganna E, McDermott MF. Spectrum of clinical features in Muckle-Wells syndrome and response to anakinra. Arthritis \& rheumatism. 2004;50(2):607-612.

129. Hoffman HM, Rosengren S, Boyle DL, Cho JY, Nayar J, Mueller JL, et al. Prevention of cold-associated acute inflammation in familial cold autoinflammatory syndrome by interleukin-1 receptor antagonist. Lancet. 2004;364(9447):1779-1785.

130. Aksentijevich I, Nowak M, Mallah M, Chae JJ, Watford WT, Hofmann $\mathrm{SR}$, et al. De novo CIAS1 mutations, cytokine activation, and evidence for genetic heterogeneity in patients with neonatal-onset multisystem inflammatory disease (NOMID): a new member of the expanding family of pyrin-associated autoinflammatory diseases. Arthritis Rheumatology. 2002;46(12):3340-3348.

131. Hull KM, Drewe E, Aksentijevich I, Singh HK, Wong K, McDermott EM, et al. The TNF receptor-associated periodic syndrome (TRAPS): emerging concepts of an autoinflammatory disorder. Medicine. 2002;81(5):349-368.

132. Demidowich A P, Freeman A F, Kuhns D B, Aksentijevich I, Gallin JI, Turner ML, et al. Brief report: genotype, phenotype, and clinical course in five patients with PAPA syndrome (pyogenic sterile arthritis, pyoderma gangrenosum, and acne). Arthritis \& rheumatism. 2012;64(6):2022-2027. doi: 10.1002/art.34332.

133. Manouvrier-Hanu S, Puech B, Piette F, Boute-Benejean O, Desbonnet A, Duquesnoy B, et al. Blau syndrome of granulomatous arthritis, iritis, and skin rash: a new family and review of the literature. American journal of medical genetics. 1998;76(3):217221.

134. Wipff J, Costantino F, Lemelle I, Pajot C, Duquesne A, Lorrot M, et al. A large national cohort of French patients with chronic recurrent multifocal osteitis. Arthritis \& rheumatology. 2015;67(4):11281137. doi: $10.1002 /$ art.39013.

135. Jesus AA, Osman M, Silva CA, Kim PW, Pham TH, Gadina M, et al. A novel mutation of IL1RN in the deficiency of interleukin-1 receptor antagonist syndrome: description of two unrelated cases from Brazil. Arthritis \& rheumatism. 2011;63(12):4007-4017. . doi: 10.1002/art.30588.

136. Aksentijevich I, Masters SL, Ferguson PJ, Dancey P, Frenkel J, van Royen-Kerkhoff A, et al. An autoinflammatory disease with deficiency of the interleukin-1-receptor antagonist. The New England journal of medicine. 2009;360(23):2426-2437. doi: 10.1056/NEJMoa0807865.

137. Ling E, Zeltser R, Makarov V. A case of cherubism with spondyloarthropathy. International journal of rheumatic diseases. 2015;8(6):681-684. doi: 10.1111/1756-185X.12597.

138. Tüfekçi TH, Bengoa EB, Karapinar G, et al. CANDLE Syndrome: A Recently Described Autoinflammatory Syndrome. Journal of pediatric hematology/oncology. 2015;37(4):296-269. doi: 10.1097/MPH.0000000000000212.

139. Higuchi Y, Shimizu J, Hatanaka M, et al. The identification of a novel splicing mutation in $\mathrm{C} 1 \mathrm{qB}$ in a Japanese family with $\mathrm{C} 1 \mathrm{q}$ deficiency: a case report. Pediatric rheumatology online journal. 2013;11(1):41-47.

140. Pettigrew HD, Teuber S, Gershwin M E. Clinical significance of complement deficiencies. Annals of the New York Academy of Sciences. 2009;1173:108-123. doi: 10.1111/j.17496632.2009.04633.x. 
141. Dragon-Durey MA, Quartier P, Frémeaux-Bacchi V, Blouin J, de Barace C, Prieur AM, et al. Molecular basis of a selective C1s deficiency associated with early onset multiple autoimmune diseases. The journal of immunology. 2001;166(12):7612-7616.

142. Ross SC, Densen P. Complement deficiency states and infection: epidemiology, pathogenesis and consequences of neisserial and other infections in an immune deficiency. Medicine. 1984;63(5):243-273.

143. Jönsson G, Sjöholm AG, Truedsson L, Bengtsson AA, Braconier JH, Sturfelt G. Rheumatological manifestations, organ damage and autoimmunity in hereditary C2 deficiency. Rheumatology. 2007;46(7):1133-1139.

144. Hussain A, Prasad K S, Bhattacharyya D, El-Bouri K. C2 deficiency primary meningococcal arthritis of the elbow by Neisseria meningitidis sero group Y in a 12-year old girl. Infection. 2007;35(4):287-288.

145. Glass D, Raum D, Gibson D, Stillman J S, Schur P H. Inherited deficiency of the second component of complement. Rheumatic disease associations. The Journal of clinical investigation. 1976;58(4):853861.

146. Rosenfeld SI, Kelly ME, Leddy J P. Hereditary deficiency of the fifth component of complement in man. I. Clinical, immunochemical, and family studies. The Journal of clinical investigation. 1976;57(6):16261634.

147. Davido B, Dinh A, Lagrange A, Mellon G, de Truchis P, Perronne C, et al. Chronic gonococcal arthritis with C5 deficiency presenting with brief flare-ups: case study and literature review. Clinical rheumatology. 2014;33(9):1351-1353. doi: 10.1007/s10067-014-2643-x.

148. Reinitz E, Lawrence M, Diamond B, Keiser H, Alper C. Arthritis and antinuclear antibodies (ANA) with inherited deficiency of the sixth component of complement (C6). Annals of the rheumatic diseases. 1986;45(5):431-434.

149. Lee TJ, Snyderman R, Patterson J, Rauchbach AS, Folds JD, Yount WJ. Neisseria meningitidis bacteremia in association with deficiency of the sixth component of complement. Infection and immunity. 1979;24(3):656-660.

150. Corvini M, Randolph C, \& Aronin S I. Complement C7 deficiency presenting as recurrent aseptic meningitis. Annals of allergy, asthma, \& immunology. 2004;93(2):200-205.

151. Alcalay M, Bontoux D, Peltier A, Vial MC, Vilde JM, Wautier JL. C7 deficiency, abnormal platelet aggregation, and rheumatoid arthritis. Arthritis \& rheumatism. 1981;24(1):102-103.

152. Jiménez Balderas FJ, Rico Rosillo G, Bravo Gatica C, Mintz Spiro G. Functional abnormalities of complement in familial and sporadic ankylosing spondylitis. Archivos de investigación médica. 1989;20(1):79-86.

153. Brickman C M, Tsokos G C, Balow J E, Lawley TJ, Santaella M, Hammer $\mathrm{CH}$, et al. Immunoregulatory disorders associated with hereditary angioedema. I. Clinical manifestations of autoimmune disease. Journal of allergy and clinical immunology. 1986;77(5):749-757.

154. Rottem M, Miron D, Shiloah E, Horovitz Y and Schlezinger M. Properdin deficiency: rare presentation with meningococcal bone and joint infections. The Pediatric infectious disease journal. 1998;17(4):356358.

155. Rieux Laucat F, Magerus Chatinet A. Autoimmune lymphoproliferative syndrome: a multifactorial disorder. Haematologica. 2010;95(11):1805-1807. doi: 10.3324/haematol.2010.030395.

156. Pun T, Chandurkar V. Growth hormone deficiency, short stature, and juvenile rheumatoid arthritis in a patient with autoimmune polyglandular syndrome type 1: case report and brief review of the literature. ISRN Endocrinology. 2011;2011: 462759. doi:

\section{$10.5402 / 2011 / 462759$}

157. Stepensky PY, Wolach B, Gavrieli R, Rousso S, Ben Ami T, Goldman V, et al. Leukocyte Adhesion Deficiency Type III: Clinical Features and Treatment With Stem Cell Transplantation. Journal of pediatric hematology/oncology. 2015;37(4):264-8.

158. Nazir S, Sayani N, Phillips P H. Retinal hemorrhages in a patient with dyskeratosis congenita. Journal of AAPOS. 2008;12(4):415-7.

159. Sadeghi Shabestari M, Vesal S, Jabbarpour Bonyadi M, de Villatay JP, Fischer A, Rezaei N. Novel RAG2 mutation in a patient with T- B- severe combined immunodeficiency and disseminated BCG disease. Journal of investigational allergology \& clinical immunology. 2009;19(6):494-496.

160. Murray JE, Bicknell LS, Yigit G, Duker AL, van Kogelenberg M, Haghayegh S, etal. Extreme growth failure is a common presentation of ligase IV deficiency. Human mutation. 2014;35(1):76-85. doi: 10.1002/humu.22461.

161. Buck D, Moshous D, de Chasseval R, MaY, le Deist F, Cavazzana-Calvo $M$, et al. Severe combined immunodeficiency and microcephaly in siblings with hypomorphic mutations in DNA ligase IV. European Journal of Immunology. 2006;36(1):224-235.

162. Bernaerts A, Vandevenne JE, Lambert J, De Clerck LS, De Schepper AM. Bare lymphocyte syndrome: imaging findings in an adult. European radiology. 2001;11(5):815-818.

163. Ben Mustapha I, Ben Farhat K, Guirat Dhouib N, Dhemaied E, Larguèche $\mathrm{B}$, Ben-Ali $\mathrm{M}$, et al. Clinical, immunological and genetic findings of a large tunisian series of major histocompatibility complex class II deficiency patients. Journal of clinical immunology. 2013;33(4):865-870. doi: 10.1007/s10875-013-9863-8.

164. Hughes CR, Guasti L, Meimaridou E, Chuang CH, Schimenti JC, King PJ, et al. MCM4 mutation causes adrenal failure, short stature, and natural killer cell deficiency in humans. The Journal of clinical investigation. 2012;122(3):814-820. doi: 10.1172/JCI60224.

165. Lopez Granados E, Porpiglia AS, Hogan MB, Matamoros N, Krasovec S, Pignata C, et al. Clinical and molecular analysis of patients with defects in micro heavy chain gene. The Journal of clinical investigation. 2002;110(7):1029-35.

166. Steuer A, Franz A, Furr PM, Taylor Robinson D, Webster AD, Hughes GR, et al. Common variable immunodeficiency presenting as a Mycoplasma hominis septic arthritis. The Journal of infection. 1996;33(3):235-7.

167. Tüngler V, Silver R M, Walkenhorst H, Günther C, Lee Kirsch M A. Inherited or de novo mutation affecting aspartate 18 of TREX1 results in either familial chilblain lupus or Aicardi-Goutières syndrome. British journal of dermatology. 2012;167(1):212-4.

168. Dotis J, Panagopoulou P, Filioti J, Winn R, Toptsis C, Panteliadis C, et al. Femoral osteomyelitis due to Aspergillus nidulans in a patient with chronic granulomatous disease. Infection. 2003;31(2):121-4.

169. Dickinson RE, Milne P, Jardine L, Zandi S, Swierczek S, McGovern $\mathrm{N}$, et al. The evolution of cellular deficiency in GATA2 mutation. Blood. 2014;123(6):863-74

170. Ombrello MJ, Remmers EF, Sun G, Freeman AF, Datta S, TorabiParizi P, et al. Cold urticaria, immunodeficiency, and autoimmunity related to PLCG2 deletions. The New England journal of medicine. 2012;366(4):330-338. doi: 10.1056/NEJMoa1102140.

171. Nita IM, Genel F, Nilsson SC, Smart J, Truedsson L, Choo S, et al. Molecular characterization of two novel cases of complete complement inhibitor Factor I deficiency. Molecular immunology. 2011;48(8):1068-1072. doi: 10.1016/j.molimm.2011.01.012. 